\title{
The European Cultural Code in A.I. Solzhenitsyn's Prose: Specific Features of Artistic Functioning
}

\author{
Guzel Golikova \\ Olga Volkova \\ Olga Palutina
}

\author{
Kazan (Volga Region) Federal University, Russian Federation \\ Email: guzel-golikova@yandex.ru,volkova006@mail.ru,opalutina@mail.ru
}

Doi:10.5901/mjss.2015.v6n3s2p121

\begin{abstract}
The article considers some features of artistic functioning of the European cultural code in certain works by A.I. Solzhenitsyn (the story "Matryona's Place" and the novel "The First Circle"). Consistency of the writer's reference to a medieval Western code, despite its traditional character and close interaction with the Russian classical tradition, is determined by the special outlook of the author, poetics of his creative work and the tasks facing the writer in artistic realization of each concrete work. The theme of Russia (authentic, "nutryanaya"), vividly presented in the story "Matryona's Place" through the symbolic image of Matryona, is a connecting thread not only with the Russian classical tradition and Biblical imagery, but also with the medieval novel about Tristan and Isolde which enables the writer to expressively highlight the opposition "true - false", including the level of implication, to strengthen the realization of the "vice versa" principle and the principle of "false mirrors". The camp theme stated in the novel "The First Circle" logically leads the writer to Dante's "Divine Comedy", to "Dante's" code, forming not only ideological and symbolic value of the novel, but also its architectonics. The symbolics of a circle organizes the chronotopes of the novel, Stalin's hell circles and the horizontal of Non-freedom. The knightly code through the writer's reference to the Grail symbolics and his symbolic search, which is transformed into the search of Truth and Verity in a totalitarian state, forms a moral and philosophical core of the work, a special symbolics - the symbol of a ladder, the way of the knight up to the Grail Castle, which forms a symbolic vertical of Freedom and turns the motive complex of the novel (first of all - the motives of nativity, resurrection, lavation, moral rebirth, etc.) into special moral and philosophical integrity. The genuine "Russianness" of the writer solving in his creative work not only concrete historical problems, but also the problems of moral and philosophical character in search of universal human values, the Truth, the Verity, the Perfection, brings him to a wide field of the West European culture, in particular, of the medieval one.
\end{abstract}

Keywords: cultural code, symbolism of Solzhenitsyn's prose, circle symbolics, Dante's code, text architectonics, ladder symbolics, image of Grail, moral lavation and rebirth motive

\section{Introduction}

A.I. Solzhenitsyn's creative work is one of the brightest phenomena not only of the Russian, but also of the world literature. Both Western and Russian scientists devoted their works to studying this author's oeuvre. The works of Western critics examine the biography of the writer, his connection with the Russian classical tradition, the specifics of his world outlook (works and articles by Durg (1972), Barker (1977), Nielsen (1975), Scammell (1984) etc.). The works of Russian literary critics of the post-Perestroika period make an objective evaluation of A.I. Solzhenitsyn's creative work, the originality of his artistic method and thinking, the themes and topics of his works, the features of style and genre, the system of characters, the symbolic character of his prose, the specifics of motive structure, etc. (V.A. Chalmayev, M. Geller, V. Lakshin, P. Palamarchuk, A. Latynina, A. Arkhangelsky, A. Vail, P. Genis, V. Bondarenko, R. Tempest, G. Friedlander, A. Nemzer, V. Surganov, T. Vinokur, D. Shturman, R. Gulya, S. Zalygina, V. Zhivov, Yu. Dedkov, V. Evsyukov, and many others). A special place in the analysis of A.I. Solzhenitsyn's creative work belongs to the works by Zh. Niva $(1990,1992)$.

The well-known writer still causes disputes. At the same time it is possible to speak of his works as a special phenomenon of realistic Russian prose, which has become property of the Western reader as well. The analysis of the whole series of his works in criticism and literary studies, since the 1970s, has allowed revealing the features of aesthetics of the writer's works, the main regularities of his artistic work whose main principle could be identified as a high 
level of the Truth. "... It is the truth of the Russian artist about his nation" (Bondarenko, 1989, p. 10). The works of the writer are deeply historical - they represent a document of his era, incorporate original facts of history, which influences both the scope of the writer's creative work, the poetics of his works, and the specifics of their genre.

The writer's creative work is a phenomenon of the unity of inner source. "The writer 'is faithful' to one or several main themes, which internally define the unity and the integrity of his creative work" (Golikova, 1998, p. 9). The main theme of his books is not only the theme of Russia, its historic past, but also, certainly, the theme of the totalitarian state, the System and the individual. This determines "... the extraordinary artistic scope and moral glow of his creative work, its place in modern Russian literature" (Friedlander, 1993, p. 93).

A.I. Solzhenitsyn is a genuine Russian artist. He constantly addresses the traditions of the Russian classical prose, Russian national poetry. In his prose the tradition of "teaching" started by A. Radishchev is particularly prominent - the writer as the tutor of the society and the interlocutor of the power (Tempest, 1993, p. 183). Solzhenitsyn's characters become bearers of his author's position, which is quite traditional for the Russian literature. The writer's characters are ordinary people born on the wrong side of the tracks, but capable to hold out, to defend their moral choice in life whether in a camp hell or in a grey daily routine. He is interested in the features of the Russian national character and the ways of its formation. Truth and Verity define the criteria of characters' evaluation in the works of the writer, especially of the characters of "flash fiction": honesty - lie; courage - cowardice; spirituality - despiritualization, etc. These categories also determine the dichotomy of images, which is typical of the author's works: "there are practically no neutral characters as there is only one truth ", - emphasizes V. Kuzmin (Kuzmin, 1994, p. 92).

A.I. Solzhenitsyn's language is also special. Its syntax is strongly "russified", "in keeping with the spirit of proverbs which were at one time Solzhenitsyn's daily reading, like a prayer book" (Niva 1990a, p. 32). The writer's language is close to national dialects, Russian song traditions, and Russian epos. In each of his works we come across dialect lexis, Russian proverbs and sayings.

Thus, Solzhenitsyn's creative work is somewhat permeated with the "currents" of the Russian tradition (classical literary, national folklore, orthodox Christian), refracted in light of realization of the camp theme and problematics, the theme of Russia and its tragic historic past. Nevertheless, the writer's "Russianness", the traditional character of his creative work enters into close interaction with the European cultural code. One could say with certainty that in A. Solzhenitsyn's works with their multidimensional poetic structure the European medieval code becomes actual, which determines special "involvement" of the writer's prose in the European cultural context. The objective of this research is to reveal the features of functioning of the European cultural code in the writer's works. The objects of the research are A.I. Solzhenitsyn's works, in which the writer's "exit" to the European cultural field is presented most vividly - the story "Matryona's Place" and the novel "The First Circle" which were written practically during the same time interval. The methodological bases of the research are scientific works on Solzhenitsyn's prose, in which the features of poetics of his prose, the functioning of symbolic imagery, and the specifics of composition are considered. The main research methods are cultural and historical, structuralist and comparative methods.

\section{The Symbolic Character of A.I. Solzhenitsyn's "Flash Fiction" and the Functioning of the European Cultural Code in the Story "Matryona's Place": The Principle of "Substitution"}

A. Solzhenitsyn in his prose and creative work generally demonstrates special artistic thinking: he comprehends concrete historical realia in the light of eternal values. The writer "... in an extremely condensed form with a tremendous artistic force... reflects upon eternal questions" (Loktionova, 1994, p. 33). In search of Truth and Verity A. Solzhenitsyn relies on the categories of Good and Evil, their furious opposition in historical reality, and this expands the author's cultural field and creates the conditions for exit into a wider cultural space - the European and the world ones. The symbolics of his works, the existence of the whole complex of symbolic imagery becomes, in our opinion, one of forms of inclusion of the author's text in the European context. A. Solzhenitsyn has a strong sense of the symbolic character of life, his works create "... the effect of motionless transparent water for us to slowly contemplate the things described in the story (novel) and attach significance to each trifle, because the History is embodied in trifles" (Arkhangelsky, 1990, p. 21). The writer's prose is generally "characterized by the effect of a sign oversupply" (Arkhangelsky, 1990, p. 21). Christian motives are presented most vividly: the symbolism in the writer's works is closely connected with the images of Orthodoxy, the books of the Old and the New Testament. The characters of his personages correspond not only to Biblical imagery; the symbols in the writer's works are logically connected with the Russian classics as well (N. Gogol, N. Nekrasov, V. Bryusov). The exception, perhaps, is the novel "The First Circle" in which the symbols of Catholic Christianity and the knightly Middle Ages are presented. On the whole, "A. Solzhenitsyn's creative work is saturated with various signs and omens, both music and light ones" (Niva, 1990b, p. 217). 
Nevertheless, already in the story "Matryona's Place" (1963) the writer's "exits" into the field of the West European culture are planned. It is well-known that the story laid the foundation of the "rural" prose in the Russian literature of the second half of the XX century: "from it, like the domestic prose of the 19th century from Gogol's "Overcoat", came our rural literature" (Lakshin, 1990, p. 116). One could see similarity of "Matryona's Place" with L. Tolstoy's moral prose (Reshetovskaya, 1984, p. 59). The story also carries on the traditions of Leskov's narrations about the Russian righteous people (Palamarchuk, 1991, p. 16). At the same time the work is saturated with special symbolics. The central image of the story - Matryona's image - is often considered from the point of view of Biblical tradition. Thus, Zh. Niva in the 70s of the XX century noted that the heroine seems to him "...the image of the Russian fate, which is poor in 'benefits', but going up directly to the blessings of the Sermon on the Mount" (Niva, 1990b, p. 209). A. Arkhangelsky correlates Matryona's image with the Bible characters - Maria and Marfa (Arkhangelsky, 1990, p. 22). She is the very personality who embodied, "... as Soloviev said, not what people think about themselves, but what God thinks about people" (Arkhangelsky, 1990, p. 22). "Expanding" the image of the heroine, literary critics rank her together with the images of old women of the Russian "rural" prose: Anna in "The Last Term" by V. Rasputin, the old woman from a series of short stories of V. Astafyev "The Last Tribute". "The unexpected effect of psychological expansion, enlargement of a portrait is created. This very heroine with her simple worries and humble joys... may be the brightest symbolic character ... - in the creative work of Solzhenitsyn" (Chalmayev, 1994, p. 84).

The "expansion" of the portrait of the heroine also takes place through the implicational allusion to the medieval European novel about Tristan and Isolde, which at some point was mentioned by A. Arkhangelsky (Arkhangelsky, 1990). It is worthy of note that in the story "Two Matryonas" Faddei, having come from captivity, marries a woman with the same name, "substitutional", unreal Matryona, like Tristan, who marries Isolde of the White Hands, not being able to reunite with Isolde the Fair. This very motive is presented in Solzhenitsyn's work. Obviously the writer's story differs from the well-known medieval novel from the point of view of conceptual messages. But at the same time the medieval European code is necessary for the author in realization of the principle of substitution and the "vice versa" principle which play the leading symbolic role in the story. At the level of implication the writer reveals to the reader this tragic historical substitution: after all, there are two Russias, as well as two Matryonas, in the story. One is genuine; the other one is "substitutional". The principle of substitution organizes the oppositions characteristic of the writer's "flash fiction" poetics. The opposition Matryona - Faddei corresponds to the main opposition in Solzhenitsyn's creative work - Good and Evil. At the same time "extra high-ranking and extra class" Matryona resists, first of all, the State which forced her to live in such a way: in poverty, without happiness, without a family (Chalmayev, 1994, p. 87). Owing to that the above-named opposition turns into the opposition "Matryona - the State". The genuine, "nutryanaya" Russia has its symbolic poetic name - the High Field, the other, "substitutional" Russia is given a sad abbreviated name - "Torfoprodukt". Here all the values are displaced and realized according to the "vice versa" principle, the principle of destruction of everything primordial and human: majestic woods have been cut down, instead of houses there are dirty barracks, the air is impregnated with smoke, the air is torn with the shrill of steam engines, "in the evening the radio-gramophone will split its sides over the club doors, and drunken men will wander down the street and stab each other with knives".

The concrete historical realia are shown through the prism of eternal values which logically leads the writer not only to Russian, but also to the European heritage. It also affects the genre nature of the story. The story is defined both as a poem (V. Shalamov), and a parable report or a sketch (Zh. Niva). At the same time we see the medieval genre of life which enables the author to reveal one of the most important thoughts of the work: Matryona is a righteous person, without whom neither the village, nor the whole our earth can hold out. Matryona's death at the end of the story symbolically reveals the death of everything genuine and real.

\section{Forms of Functioning of the European Cultural Code in the Novel "The First Circle": The Symbolics of a Circle and a Ladder}

Most brightly and conceptually the European cultural code is realized in the novel "The First Circle" which has had seven editions and become one of the phenomena in A.I. Solzhenitsyn's creative work still not completely investigated in criticism and literary studies. The reference to the Western culture is determined by the very title of the novel. The theme of a camp hell metaphorically is defined by the image of the Hell from Dante's "Divine Comedy". In the second chapter of the novel "Dante's Idea" Solzhenitsyn himself explains why he turns to the great Italian: "... Dante came up with "sharashka", if you like... Dante was in two minds: where he should place ancient wise men... And he invented a special place for them in hell" (Solzhenitsyn). "Dante's" code organizes the whole space of the text, the architectonics of the novel, smoothly uniting with Christian and knightly traditions, in a special way organizes its motive and symbolic structure. Solzhenitsyn, like Dante, uses the symbolical number three, first of all, in the organization of the novel's chronotope. The 
writer "squeezes the artistic time covering a lot of people, into only three days: the action begins on Saturday afternoon, on December 24, 1949 (the lacy hands on the clock in the Foreign Ministry office of the Class II State Councilor Innokentii Volodin showed five minutes past four), and it finishes on Tuesday afternoon, on December 27" (Golubkov). Number "three" which in Dante's work symbolizes the Christian Trinity, in Solzhenitsyn's novel is also determined by his Christian outlook, but, at the same time, it is connected with the Russian folklore traditions - allusion to the fairy tale, even to the epic imagery (three central heroes in the Marfino sharashka at a symbolic crossroads).

The image of Dante's hell marked by the well-known quote inserted into the novel ("Abandon hope all ye who enter here") and projected onto Stalin's time, logically "dictates" a special architectonics of the work. Here an important place belongs to the circle symbolics (confined space), which is characteristic of the writer's creative work, and distinctly shown already in the titles of the most significant works of Solzhenitsyn - "Matryona's Place", "One Day in the Life of Ivan Denisovich", "The Cancer Ward" and, at last, "The First Circle". Even in the title of the artistic research experience "The Gulag Archipelago" there is a peculiar allusion to circle symbolics through the ring-shaped rhythmic organization of the title of the book. We see practically all the circles of a camp hell presented in Solzhenitsyn's creative work. And the epic "The Red Wheel" becomes a logical explanation of where this hell came from. The symbolics of a circle is effectively realized through the poetics of "confined" spaces. In the most renowned books of the writer "... the action develops in a confined space, most often artificially created, with its accurately outlined topography, its own chronology, and its own vital rhythm". The exception is the epic "The Red Wheel" which can be considered as "... the writer's exit-breakthrough from the literary text into another space, which is open, flat, historical" (Tempest, 1993).

The circle symbolics in a special way organizes the novel space of "The First Circle", including the novel chronotopes, which "are similar to circles lying in one plain" (Golubkov). In the camp hell depicted by Solzhenitsyn the Marfino sharashka becomes the first circle where the best minds of Stalin's era "reside". The symbolic image of the Marfino sharashka becomes a certain sacral space of Truth-Conscience-Perfection, a peculiar purgatory, providing the unity of the narration and the unity of characters, like the union of the Knights of the Round Table (Golikova, 2014). Only one of the hell circles - the initial one - seems to be defined in the novel, but, as a matter of fact, the author has made an attempt to describe the hell at large. The hell circles are not limited only by the camp life. A special circle presents the socalled "freedom". The writer investigates each of the circles and draws a conclusion: outside sharashka there is no freedom either, there is no liberty, there is Hell everywhere. Vividly manifesting the theme of freedom and, first of all, of inner freedom, the author shows that in Stalin's state there is no freedom anywhere, neither in a camp, nor outside the camp. The whole State is also a camp, a Non-freedom camp. The writer expresses a counterintuitive thought, which will also appear in the story "One Day in the Life of Ivan Denisovich" (1962): it is in the camp where one could gain inner freedom the bearers of which are pure souls, such as Gleb Nerzhin. The "Non-freedom" horizontal (its numerous circles in the horizontal plain) enters into an internal conflict with the Vertical of Freedom which in the architectonics of the novel is characterized by special symbolics - the image of a ladder, the road up connected with the theme of appeal to the Sky (Rzhevsky, 1972).

The image-symbol of a ladder is particularly effective in the episode of Klara Makarygina's enlightenment. The reader can see one more "awakening" though here the process is only planned (Rzhevsky, 1972, p. 97). An untidily dressed woman washes the ladder in a house where Prosecutor Makarygin's family gets a new apartment. The washing of a ladder is a deeply symbolic episode sacrally connected with the motive of lavation, which Solzhenitsyn connects with the motive of finding the Truth, which for the writer is the same as gaining inner freedom.

In his novel Solzhenitsyn transforms the image-symbol of a ladder into a symbolical way of a knight who is climbing the rocks to the Grail Castle. Depicted in a painting by the camp artist Kondrashev-Ivanov, the Grail Castle, certainly, has a symbolical sense. Chapter "The Castle of the Holy Grail" itself is "a mysterious center of the work, the center conveying the sense" (Niva, 1990b, p. 220). The symbolic image of Grail is a key in understanding ideological (moral and philosophical) sense of "The First Circle", it determines its spiritual measurement, it is closely connected with Solzhenitsyn's moral and spiritual views and influences its composition and narration structure, space-time coordinates, the principles of creation of the characters' images system (Golikova, 2014). The essense of the painting is connected with the outlook of the writer - his moral and religious mindset, the belief in finding the Spirit and its greatness. Grail in the novel is certainly a multidimensional symbol, but it can be initially understood as search of Truth, overcoming sinfulness of existence, a way to moral purification and Perfection. With Solzhenitsyn it is a way to the Truth. That is why in comparison with dark and gloomy descriptions of Stalin reality and the Marfino sharashka, the Grail Castle is described in bright colors, which is also deeply symbolic: over the mountain gorge there is a rider. In amazement and embarrassment he is looking into the distance, "... where all the top space of the sky is covered with orange-golden shine" and "vague but still detectable in the details of strange perfection, the Castle of the Holy Grail was standing in its radiant halo" (Rzhevsky, 1972, p. 99). 
The knightly story about Grail in a special way highlights the motive of moral revival shown in the novel, which the characters of the work, first of all, Gleb Nerzhin and Innokentii Volodin, arrive at. Solzhenitsyn projects the medieval story about Grail onto the novel's plot and system of characters. In the knightly cultural code the special role in search of Grail is played by the two heroes - knights Perceval and Galahad. Unlike innocent, plain, and even pampered Perceval, Galahad is perfect both in spirit and body. Galahad is intended to be the hero of Grail. It is quite obvious who "plays" the role of Galahad and who the one of Perceval in Solzhenitsyn's novel - these are Nerzhin and Volodin respectively. Galahad's image in the novel was discovered by Zh. Niva when he wrote that "Nerzhin invites his friends to go down to hell circles in the same way as Galahad gathers people and talks them into looking for Grail". Galahad and Perceval are at different stages on the way to Grail, as in Solzhenitsyn's novel, but, nevertheless, both are the elects. Descending to prison hell becomes a form of ascension to Perfection (Golikova, 2014).

"Dante's" and knightly codes let the writer not only organize the structure of the novel at all levels, but also express own values in more detail, to reveal his world outlook. Without doubt, A. Solzhenitsyn's artistic prose and publicistic writing inherit religious and philosophical views from the Russian classical writers, first of all, F.M. Dostoyevsky (Sokhryakov, 1994). A.Solzhenitsyn is close to F. Dostoyevsky, their thoughts are related to each other (Krasnov, 1980). "For them there is one criterion of social life, in fact, a very simple one - the priority of the individual" (underlined by us G.G.) (Saraskina, 1994, p. 116). At the same time the novel "The First Circle" distinguishes one more author, who Solzhenitsyn is guided by, whose humanistic view on the world has an essential impact on Solzhenitsyn - this is Dante. Dante's vision is distinctly shown at the level of style as well. The reader sees his irreconcilable view on the existing state of affairs, his pitiless author's irony (tragic at its core) exposing lie and injustice.

\section{Conclusions}

The artistic prose of A. Solzhenitsyn is penetrated with dialectics of superficial and intimate, visible and invisible (Niva, 1992, p. 54). Following the logic of his own poetic vision, A. Solzhenitsyn brightly actualizes and skillfully interweaves the European cultural code into the artistic fabric of his works. Thus he addresses the medieval code expressed through the stories about Tristan and Isolde, about Grail, through the reference to "Dante's", code and creates a special symbolic and philosophical core of his works, defines the principles of organization of the whole narration. The writer is strongly attracted by the Middle Ages, "in many works by Solzhenitsyn one could come across spiritual values" of this era "in a new light", as "he is attracted by the integrity of people's outlook of those times, their focus on spiritual issues and their neglect of the earthly ones" (Lopukhina-Rodzyanko, 1974, p. 24). Solzhenitsyn's attention is drawn by asceticism of a medieval person (he was an ascetic himself), the urge to find a perfect Soul, the Ideal, Perfection.

The European medieval code is transformed in compliance with the author's perception of the world, which is based on the Christian belief, closeness to the Russian classics and the Russian national traditions, and also the ideas of repentance and self-restriction. Thus, in the story "Matryona's Place" the European cultural code acts in the form of implication, a hint and is at the same time connected with the organization of the internal principle in work composition the principle of "substitution", the "vice versa" principle (peculiar false mirrors), forms the opposition "true - false" through the implementation of the images of two Matryonas.

The European medieval code is most vividly and naturally presented in the novel "The First Circle" which is shown through symbolic imagery and a special structure of the novel. The symbolics of Grail shown through updating knightly stories about his search structures a moral and philosophical kernel of the text. The symbolic way to Grail becomes a symbol of gaining inner freedom through finding Truth and Verity in the state of Lie and Non-freedom. Through the circles of a camp Hell to gaining inner Freedom.

The projection of Dante's hell onto the text of the novel narration enables the author to organize the poetics of "confined" spaces in a new way, updating the circle symbolics to create special novel chronotopes (space-time circles), to create complicated architectonics, which is based on the vertical of Freedom and the horizontal of Non-freedom. The medieval Western code in a special way highlights the main motive complex of the novel - the motives of nativity, resurrection, moral lavation, and rebirth, search of Truth, enables to connect concrete historical, autobiographical and universal matters, to reveal eternal values, the central ones for the writer being the Individual and Freedom, to bring together the Russian and West European cultures through their natural interaction.

\section{References}

Arkhangelsky, A.O. (1990). O simvole bednom zamolvite slovo: "Malaya" proza Solzhenitsyna: "poeziya i pravda" [Speak about the poor symbol: Solzhenitsyn's "flash fiction": "poems and truth"]. In: Literaturnoye obozreniye, \#9, 20-24. 
Barker, F. (1977). Solzhenitsyn: Politicsaform. London.

Bondarenko, V. (1989). Sterzhnevaya slovesnost': O proze A. Solzhenitsyna [Stalky literature: about A. Solzhenitsyn's prose]. Lit.Rossiya.- May, 26. (\#21), 10-11.

Chalmayev, V. (1994). Alexander Solzhenitsyn. Zhizn' i tvorchestvo: kniga dlya uchaschikhsya [Alexander Solzhenitsyn. Life and creative work: book for students]. Moscow: Prosveschenie, 287p.

Durg, D. (1972). Solzhenitsyn. New York.

Friedlander, G.M. (1993). O Solzhenitsyne i ego estetike [About Solzhenitsyn and his aesthetics]. Rus.Lit. \#1, 92-99.

Golikova, G.A. (1998). Izucheniye tvorchestva Solzhenitsyna v natsionalnykh shkolakh Respubliki Tatarstan: avtoref. diss. kand. ped. Nauk [Studying Solzhenitsyn's creative work in national schools of the Republic of Tatarstan: abstract of PhD thesis], p.9.

Golikova, G.A. (2014). Simvolika Graalya v avtobiograficheskoi proze A.I. Solzhenitsyna [Symbolics of Grail in autobiographical prose of A.I. Solzhenitsyn]. In: Filologicheskie nauki. Voprosy teorii I praktikti, \#5, 58-61.

Golubkov, M. "V kruge pervom". Opyt monograficheskogo analiza: zhanr, problematika, syuzhet b kompozitsya, sistema personazhei ["The First Circle". Experience of monograph analysis: genre, problematics, plot and composition, the system of characters]. [Online] Available: http://www.dissercat.com/content/roman-i-solzhenitsyna-v-kruge-pervom-problematika-i-poetika\#tixzz2oV2 Ada2A

Krasnov ,V. (1980). Solzhenitsyn and Dostoevsky: A Study in the polyphonic novel. Athens: The Univ. of Georgia Press.

Kuzmin, V.V. (1994). Khudozhestvenny monism Solzhenitsyna: "Malaya" proza [Artistic monism of Solzhenitsyn: "flash fiction"]. In: Zhanrovo-stilevye problem russkoi literatury XX veka. Tver, 89-102.

Lakshin, V.Ya. (1990). Puti zhurnalnye: iz lit. polemiki 60-h gg. [Journal paths: from literary polemics of the 60s]. Moscow: Sovetsky pisatel, 426p.

Loktionova, N. (1994). "Ne stoit selo bez pravednika": k izucheniyu rasskaza A. Solzhenitsyna "Matryonin dvor" (na urokakh lit.) ["There is no village without a righteous man": for study of A.Solzhenitsyn's story "Matryona's Place"(at literature lessons)]. In: Literatura $v$ shkole, \#3, 33-37.

Lopukhina-Rodzyanko, T. (1974). Dukhovnye osnovy tvorchestva Solzhenitsyna [Spiritual base of Solzhenitsyn's creative work]. Frankfurt am Main: Posev, $180 \mathrm{p}$.

Nielsen, N. (1975). Solzhenitsyn's religion. New York.

Niva, Zh. (1990a). Pisat' po-russki!: iz kn. (fr. Slavista) "Solzhenitsyn"[To write in Russian: from the book (fr. slavist) "Solzhenitsyn"]. In: Russkaya rech. \#5, 19-34.

Niva, Zh. (1990b). Solzhenitsyn: Glavy iz knigi: /Perevod s fr. S. Markish v sotrudnichestve s avtorom [Solzhenitsyn: Chapters from the book: translation from French by S. Markish in collaboration with the author]. In: Druzhba narodov, \# 5, 203-252.

Niva, Zh. (1992). Solzhenitsyn: translated from French. Moscow: Khudozh. Lit., 189 p.

Palamarchuk, P. (1991). Solzhenitsyn: Putevoditel' [Solzhenitsyn: Guide]. Moscow: Stolitsa, 96p.

Reshetovskaya, N. (1990). Alexander Solzhenitsyn i chitayuschaya Rossiya [Alexander Solzhenitsyn and reading Russia]. Moscow: Sov. Rossiya, $416 \mathrm{p}$.

Rzhevsky, L. (1972). Tvorets i podvig [Creator and deed]. Frankfurt am Main: Posev.

Saraskina, L. (1994). "Rossiya opyat' sobiraetsya s myslyami" (o pozdnei publitsistike F.M. Dostoevskogo i A.I. Solzhenitsyna) ["Russia pulls its wits together again" (about late publicist works by Dostoevsky and Solzhenitsyn)]. Zvezda, \#6, 109-116.

Scammell, M. (1984). Solzhenitsyn: A Biography. New York - London.

Sokhryakov, Yu. (1994). A.I. Solzhenitsyn i F.M. Dostoevsky (o parallelyakh mezhdu temami, motivami I geroyami v tvorchestve russkikh pisatelei) [A.I. Solzhenitsyn and F.M. Dostoevsky (about parallels between themes, motives and characters in Russian writers' creative work)]. In: Ross. Literaturoved. Zhurnal: teoria $i$ istoria lit., \#3, 105-112.

Solzhenitsyn, A. (1968). V kruge pervom. [The First Circle].

Tempest, R. (1993). Geroi kak svidetel': mifopoetika A. Solzhenitsyna [Hero as a witness: A.Solzhenitsyn's mythopoetics]. Zvezda, \# 10, 181-191. 